Ана Јаковљевић Радуновић

Универзитет у Београду

Филолошки факултет

Катедра за славистику

anajakovljevic@yahoo.com
УДК 821.161.1.09

https://doi.org/10.18485/slavistika.2019.23.1.21

оригинални научни рад примљено 07.03.2019.

прихваћено за штампу 16.05.2019.

\title{
БАХЧИСАРАЈСКИ ДВОРАЦ КАО МЕСТО СЕЋАҢА КОД АЛЕКСАНДРА ПУШКИНА И СЕРГЕЈА ПАРАЏАНОВА
}

Сценарио Зачарани замак (Дремлющий двореи) Сергеја Параџанова написан је по мотивима Пушкинове поеме Бахчисарајска фонтана. Полазећи од Албвашеве теорије сећања и концепта места сећања Пјера Нора, на примерима Пушкиновог и Параџановљевог текста разматран је механизам формирања појма Бахчисарајског дворца и Фонтане суза као културног места сећања.

Кључне речи: Пушкин, Параџанов, Фонтана суза, Бахчисарај, место сећања, сценарио, лично и колективно сећање.

Sergey Paradjanov's litrerary scenario Enchanted Castle (Дремлющий дворец) is based on the Puskin's poem Bakhchisarai Fountain. In our paper, by applying Maurice Halbwachs' theory of collective memory and Pierre Nora's concept of place of memory, we examine the mechanism of forming the term "Bakhchisarai Castle and Fountain of Tears" as a place of cultural memory.

Key words: Pushkin, Paradjanov, Fountain of Tears, Bakhchisarai, memory site, screenplay, collective and personal memory.

Пушкинова поема Бахчисарајска фонтана настала је по песниковом сведочењу као данак сећању на „неименовану“ „северну“ „тајну“ љубав која је своје оваплоћење нашла и у јужним поемама. ${ }^{1}$ За Параџанова Пушкинова поема је основа од које гради сложену причу о Бахчисарајском дворцу као месту у коме долази до „згушњавања“ историјског времена, причу о музеју у коме су сачувани предмети не само из различитих епоха него и из различитих култура, ${ }^{2}$ и причу о сусрету два уметника из два различита периода. У сценарију Зачарани замак (Дремлющий двореи), режисер се бави проблемима појединачног и колективног памћења, односом културе и историје, а посебну пажњу посвећује нагомилавању историје различитих култура на једном месту. Черњенко је запазио да се Параџанов увек бави периферијом културе и местима нестабилне равнотеже, где се архетипови сударају једни са другима, али се могу чувати на територији суседа, када из било ког разлога нема могућности очувања на сопственој територији (Черненко 1990: 98). ${ }^{3}$

${ }^{1}$ Раиса Владимировна Језуитова је, истражујући тему „тајне љубави“ у стваралаштву Пушкина, дала драгоцен преглед радова са темом „тајне“, „неименоване“ „петербуршке“ или „северне“ љубави (Иезуитова 1995: 211).

${ }^{2} \mathrm{O}$ Параџановљевим предметима-симболима и предметима-епиграфима детаљно смо писали у магистарском раду „Сергеј Параџанов: кинематографско читање поема Пушкина и Љермонтова“ (Јаковљевић 2004: 24-27).

${ }^{3}$ Превод овде и даље мој - А. Ј. Р. 
Дворац у Бахчисарају је специфичан културни локалитет, који повезује Пушкиново дело из 1824. године и сценарио Параџанова из 1969. године. Истражити механизам спајања могуће је кроз примену друштвене теорије сећања, коју је развио почетком двадесетог века Морис Албваш (Maurice Halbwachs). Он је први описао однос између индивидуалног (интерног, личног) и колективног (друштвеног) сећања (Куљић 2006). Прво је аутобиографско, а друго историјско и њега формирају и подржавају социјалне институције и групе (породица, црква, и друге социјалне формације). У оквирима група, институција или социјалног система сећање покреће механизам помоћу којег се одређени моменат претходног стања или процеса представља не само као део прошлости, него и као кључ за будућност, који тиме утиче на њу, а суштински повезује прошлост и садашњост. Механизам репродуковања прошлости везан је за два поступка: формирање (конструкција) и рушење (деконструкција). Према Албвашу, колективно сећање представља селективно усвајање прошлости из перспективе садашњости и увек има принудни и обавезујући карактер (Албваш 1999).

За разлику од Албваша, који сматра да се сећање и историја не могу поредити, Пјер Нора (Pierre Nora) покушава да их помири уводећи термин „место сећања" ("lieux de memoire”). Овај појам не подразумева само материјалне објекте заједничког културног сећања или историјске и културне локалитете, већ и интелектуалну традицију. Места сећања су споменици, музеји, архиве, али и празници, годишњице, меморијали, колекције и књиге. Она се формирају и као локалитети и као симболичка места везана за прошлост, а живе у свести нације све док их подржава колективно сећање. На тај начин формирају се „ритуали друштва без ритуала“. Места сећања опстају захваљујући жељи да се памти и осећању одсуства спонтаног сећања (Нора 1999).

Државна идеологија блокира лично и супкултурно сећање. За тоталитарне режиме актуелно је сећање као идеологија, уз помоћ које се разграничава шта је у прошлости вредно помена, па и похвале, шта служи као путоказ и шта је кључна ствар за формирање будућности (Барышников и др. 2011). Крим је у састав Руске империје ушао 1783. године. Пораз Татара условио је њихово повлачење из Бахчисараја и потоње пропадање Бахчисарајског дворца. Устоличењу Катарине II на канском трону, претходила је трогодишња обнова дворца, током које је Фонтана суза премештена са првобитног места, а руски двоглави орао постављен на место где је раније стајао полумесец. Споменици, меморијали и церемонијали који одликују државно сећање по правилу су краткотрајни и бивају превазиђени не само сменом режима, већ и његовом простом еволуцијом (Барышников и др. 2011). Тако су и Бахчисарајски дворац и његови споменици претрпели суштинске промене приликом освајања крајем XVIII века, а за време Пушкинове посете Криму 1820. године већ су били запуштени и изложени пропадању. Место сећања које је конструисано од стране државе није било ни аутентично ни дуготрајно. Почетком XX века дворац је претворен у музе туркијско-татарске културе да би, после депортације Кримских Татара 1944. године, престао да постоји и у тој функцији. Почетком 1967. године била је донета одлука о враћању Татара на Крим и враћању грађанских права татарском народу. Подстакнут овим променама Параџанов се упустио у испитивање симболике локалитета и у периоду између 1969. и 1972. године пише сцена-
Бахчисарајски двораи као место сећања код Александра Пуикина и Сергеја Параианова 277

рио Зачарани замак. Виктор Шкловски је у писму режисеру скренуо пажњу на могуће потешкоће: „Тема Крима, једина је за нас табуирана национална тема, зато што на Криму нема Кримских Татара...“ (Параджанов 2001: 163). Сценарио Параџанова није преточен у филм јер званични идеолози СССР-а нису дозволили да се сними филм о интернираном народу.

Трансформација легенде о Фонтани суза везана је за крај XVIII и почетак XIX века и преломну улогу у томе имало је Пушкиново дело Бахчисарајска фонтана. Путници који су у Бахчисарај долазили пре песника препричавали су легенду о кану заљубљеном у хришћанку повезујући је са турбетом које је постојало на територији дворца. Један од првих записа о тајанственој љубави Керим-Гиреја (1717-1769) среће се код Енглескиње Елизабет Крејвен 1786. године. Она описује турбе које је кан подигао у спомен на своју жену-хришћанку, после чије смрти је био неутешан (Храпунов и др. 2018). Муравјов-Апостол, који је на Криму боравио исте године кад и Пушкин, такође је забележио да је Керим-Гиреј саградио турбе „да би се сузама тешио над прахом вољене жене“ (Балакин и др. 2013). У различитим записима легенде о кановој жени се говори као о хришћанки пољског или грузијског порекла. Бронштајн је установио да су се на територији дворца налазила два споменика повезана са именом канове жене Диљаре-Бикеч: први је Зелена џамија, где се на једном од зидних натписа помиње њено име, а други је турбе са натписом: „Молитва за упокој душе преминуле Диљаре-Бикеч“ (Бронштейн 1997). Пушкинова поема потиснула је временом друге варијанте предања и трајно повезала легенду о заљубљеном кану са Фонтаном суза као јединим спомеником који је подигнут као успомена на умрлу драгу.

Песник у својим писмима од 7-8. септембра 1820. године не помиње посету Бахчисарају, а у раној варијанти његова поема је садржала само „причу о судбини заробљене Пољакиње у бахчисарајском харему“ (Балакин и др. 2013: 13) Новопронађена „полицијска посланица“, о којој пишу Балакин и Бондарева, учврстила је претпоставку да је легенда у овом облику до песника могла доћи посредством Софије Станиславовне Кисељове-Потоцке (Балакин и др. 2013). Радећи на коначној варијанти поеме, Пушкин је одлучио да провери причу „о Потоцкој коју је отео неки кан“ што је 1823. године довело до одустајања од првобитног плана. Бахчисарајска легенда у коначној варијанти поеме формирана је под утицајем колективног оквира памћења: песник је увео у свој текст обе јунакиње бахчисарајског предања и Пољакињу - Марију Потоцку, о којој су упорно говорили становници Бахчисараја, и прелепу Грузијанку - Зарему, о којој пише Муравјов. Историјат настанка текста поеме потврђује да је она резултат „судара уметничке замисли и историјског предања““(Балакин и др. 2013).

Пушкин је главни лик Параџановљевог сценарија, те је за режисера важно да покаже како је легенда о Фонтани суза као месту сећања формирана под утицајем песникове животне ситуације. „Безимена“ Пушкинова љубав предмет је дугогодишњих спорова пушкиниста. Једна од првих теорија о идентитету тајанствене жене припада Јурију Николајевичу Тињанову, који је повезује са заљубљеношћу младог писца у много година старију Катарину Андрејеву Карамзину (Иезуитова 1995). Параџанов у свом сценарију прихвата ову верзију и практично илуструје роман Тињанова. Док путује на југ, песнику се указује 
минијатура Карамзине у седефу као еквивалент сећања на догађаје на северу. Тињанов посебно истиче духовни утицај Катарине Андрејевне на Пушкина „Одједном је схватио да је целу руску историју, од времена Владимира Красног Сунца сазнао баш овде, али не од њега, већ од ње, од Катарине Андрејевне“ (Тынянов 1987: 502). Посебан део треће новеле сценарија посвећен је мотивацији песниковог доласка на Крим, а Тињановљев текст омогућио је Параџанову да прикаже однос индивидуалног и колективног сећања: у роману се наводи да је Пушкин историју учио од званичног државног историографа Николаја Карамзина, али да памти оно што је чуо од његове супруге (Тынянов 1987: 525). Одабир садржаја који ће бити боље и прецизније упамћен у односу на остале, као и то у којој ће мери меморисано остати ближе колективном моделу, зависи од субјективног избора па се књига са празним листовима у кочији материјализује под утицајем Пушкиновог сећања на жену у коју је заљубљен. Бели листови чекају да на њима буде овековечена љубавна прича због чега се централним местом сценарија може сматрати моменат у коме Катарина Карамзина изговара речи: „Фонтана суза“ (Параджанов 2001: 169). ${ }^{4}$ Бахчисарај је и код Параџанова и код Пушкина представљен као место сећања на које јунака доводи потреба да се оживи и овековечи оно чега више нема.

Сценарио садржи временску вертикалу која почиње временом Селим-Гиреја, обухвата период када је Крим постао саставни део Руске империје и завршава се 1969. годином. Дворац у коме је током времена долазило до сусрета различитих култура и њихових носилаца моћан је извор информација. Посетиоци Крима попут Катарине Друге и Суворова вођени су државним интересима, или су туристи вођени жељом да виде место од историјског значаја, али нико од њих није у стању да сагледа и схвати огромну количину информација коју дворац носи не само на историјском плану већ и у сфери уметности, због чега аутор уводи лик Човека. Стваралачка имагинација савременог уметника оживљава Бахчисарај. ${ }^{5}$ Низ објеката и предмета који се појављују у сценарију доносе слику савременог Бахчисарајског дворца и нуде нам представу о ономе што је актуелно у свести уметника који ствара уметничко дело. Сменом општепознатог и личног режисер показује сопствени однос према историји места, према народу који је овде живео, али и према уметнику који га је у свом делу овековечио. Веза песника и Човека истакнута је и прецизним навођењем година када су ова два јунака боравили на Криму. ${ }^{6}$

${ }^{4}$ Мотив неисписаних белих листова повезује Пушкинов лик са ликом песника Арутина из филма Боја нара. У делу филма под називом „Минијатура у којој се пред дечаком Арутином отвара свет лепоте и тајне“, дечак стоји на крову Санајинског манастира међу отвореним мокрим књигама. То је тренутак у коме он открива лепоту јерменских средњевековних минијатура и старих рукописа. Сусрет са старим јерменским рукописима био је увод за Арутинов улазак у свет књижевности.

${ }^{5}$ У низу сценарија Параџанов је јасно ставио до знања да је Човек уметник иза камере: на страницама сценарија Сајат Нова Парашанов је оставио забелешку: „Арутин сам ја, Сајат Нова сам ја" појављује Човек као главни јунак и није тешко утврдити да се и иза овог лика крије режисер. септембра 1820 . године, за време путовања на Крим са породицом Рајевских. Можемо прет-
Прва новела Параџановљевог сценарија почиње приказом околине дворца, којом доминирају узвишење Ћуфут-Кале и река Чурук-Су, и доноси пејзаж који су могли видети сви посетиоци, без обзира на време њиховог боравка у Бахчисарају. Река и планина припадају сфери природног и трајно постојећег Следи приказ здања, које аутор назива ремек-делом муслиманске ренесансе. После описа унутрашњег дворишта, башти, џамије, фонтане, главне џамије, базена са водом, следи харем, за који каже да „стоји са стране“. Харем се налази на периферији видног поља, чиме се истиче чињеница да је он место од мање значаја и да је предодређен за мање вредну социјалну групу (Лотман 2001: 266). Поетика приче захтева од Параџанова да приповедање отпочне далеко од главног предмета и да му се после неког времена приближи. После харема у кадру се појављује позлаћени шестоугаони кавез за фазане. Напоредост мотива харема и позлаћеног шестоугаоног кавеза ствара нераскидиву асоцијативну везу: уз сву лагодност и сјај, живот на овом месту је пре свега ропство. Мотив кавеза и са њим повезаног „златног ропства“ представља лајтмотив сценарија. Аутор ће му се више пута враћати обогаћујући га новим садржајима. Позлаћени кавез постаће симбол живота свих становника дворца: Зареме, Марије, свих Татара који су живели на територији Крима. Златно ропство повезује у Параџановљевом сценарију и Гиреја и Пушкина.

Причу о животу у дворцу режисер почиње сликом гробнице. Последњи сегмент прве новеле сценарија завршава се сликом гробља и гробнице СелимГирејеве жене. Код Параџанова настанак уметничког дела често је повезан са темом смрти и гробља. У три сценарија: Кијевске фреске (Кивеские фрески), Исповест (Исповедь) и Зачарани замак режисер приказује град у коме се прожимају и нагомилавају колективно и лично сећање. Кијевске фреске, које је требало да буду снимљене у част двадесетогодишњице ослобођења Кијева од немачке окупације, почињу у Петерхофу рушењем фигуре Самсона, а аутобиографска Исповест почиње у Тбилисију рушењем гробља на коме су почивали уметникови преци. Споменик може бити уништен у рату, али га уништава како време (постаје трошан), тако и нови обичаји које захтева савремено друштво. Кијевска фонтана је по наређењу власти расформирана 1934. године. Власти су наредиле и уништење гробља у Тбилисију на коме су почивали преци уметника. Споменици и сами постају део историјског процеса, а њихово стварање и рушење јесу лајтмотиви сва три поменута текста. Они јасно илуструју ауторово схватање да смена живота и смрти није трагична ствар, јер представља суштину живота који и јесте непрекидно кретање (Параджанов 2001: 123). Као што су способни да стварају лепо, људи су у стању и да га уништавају.

Опис посете Бахчисарају у Пушкиновом тексту појавио се приликом коначог уобличавања текста, а затим и у писму Дељвигу, написаном 1824. и послатом 1825. године, које настаје са очигледним уметничким интенцијама (Пушкин 1969: 53-54). Мали део писма наведен је и у сценарију:

поставити да за Параџанова није важно тачно историјско датирање песниковог боравка на Криму, колико тренутак када почиње да ствара дело.

${ }^{7}$ О мотиву златног кавеза детаљно смо писали у раду „Сергеј Параџанов: кинематографско читање Пушкинових и Љермонтовљевих поема““ (Јаковљевић 2004: 162-167; 207) 
280

Ана Јаковљевић Радуновић

„У Бахчисарај сам допутовао болестан. Раније сам слушао о чудном споменику заљубљеног кана.

...Обишао сам дворац разљућен немаром због којег он пропада“ (Параджанов 2001: 167).

За режисера су у писму битна само два момента: први, да је Пушкин од неког лица раније чуо причу о споменику који је подигао заљубљени кан, и Пушкиново незадовољство изазвано чињеницом да је дворац због немара изложен пропадању. Аутор сценарија изоставља део у коме се Пушкин љути због прераде неких соба у „полуевропском стилу“ које се односе на посету Катарине Друге, али у свом тексту указује на разлоге који су довели до промена у дворцу. За империјално сећање Бахчисарај је место устоличења руске царице као владара Крима. Сценом уношења позлаћеног императорског трона у „муслимански дворац“" Параџанов приказује успешан завршетак освајања (Параджанов 2001:170). Суворовљева посета Бахчисарајском дворцу имаће другачије последице за дворац и за Фонтану суза. Катаринин војсковођа који је у царичино име извршио освајања територија на Криму приказан је као човек који одлучује да од пропадања спасе споменик народа чијој је пропасти и сам допринео.

Вода која се као лајтмотив појављује у оба текста има симболичко значење које се може свести на три доминантне теме: извор живота, средство очишћења и средиште обнављања (Chevalier и др. 2003: 755-760). Фонтане су посебна места која настају као израз људског уверења да је изворска вода дар мајкеземље, баш као што су киша и роса дар неба. Млазеви воде који извиру из земље и истовремено падају с неба обухватају у себи двоструки дар. Фонтана која данас постоји у Бахчисарају и која је позната под називом Фонтана суза представља „салсабил“. Овакве фонтане традиционалне су за исламску архитектуру. Првобитна њена улога била је јавна доступност воде која исцељује на шта указује и њен првобитни положај у оквиру дворца, као и натпис на самој фонтани (Howard 2002: 177). За песника и Човека Фонтана суза је место намењено само изабранима: арапска реч „салсабил“ означава „тражење излаза, гутање задовољства, вода са извора“, те у теолошком смислу она представља кретање од пуког егзистенцијалног утољавања жеђи до пијења са духовног извоpa (Howard 2002: 177-178). Нагли пљусак у Бахчисарајском дворцу послужиће режисеру да покаже разлику између уметника и „гомиле“. Туристи се склањају од кише, покривајући се пластичним кабаницама, а песник стоји на пљуску одевен само у свој реденгот. Чињеница да у одајама царице, џамији, радионици за рестаурацију, чак и у Фонтани суза, као и у свим деловима дворца одзвања звук кишних капи знак је обнављања и оживљавања простора. Здања, предмети и споменици који се односе на далеке епохе и другу културу и даље учествују као живи фактори у културном развоју државе која их је „присвојила““

Паралелном сликом жутих покислих улазница и жутих латица ружа, које се осипају због кише, режисер уводи још једну бинарну опозицију којима приказује дисхармоничност и трагичну дисонанцу постојања. Жуто може бити боја вечности и еквивалент је злата као метала вечног живота. У овом значењу жуто је везано за Пушкина као представника златног века руске књижевности и „Сунца“" руске поезије. Са друге стране, жуто је боја природе у јесен, најављује
Бахчисарајски дворац као место сећања код Александра Пуикина и Сергеја Парацанова 281

слабост, старење и долазак смрти. У овом смислу жуто је амблем пролазности. Жуте улазнице, које водичи брижљиво чувају, не отварају сва врата дворца. Туристи нису у стању да сагледају стварни значај овог места, нити су свесни временске вертикале која у њему постоји, њима је доступна само садашњост и тренутна слика дворца те је зато жуто у овом контексту боја пролазности земаљског и заборава. Посетиоци виде дворац, али је уметник тај који овде види живог Пушкина. Песник у рукама држи брескву, која је симбол бесмртности, али и обећање новог почетка, будући да својим цватом најављује долазак пролећа (Chevalier i dr. 2003: 61-62). После сцене у којој Пушкин једе брескву, Параџанов описује како вода продире у радионицу за рестаурацију. Изложеност предмета стихији не указује на њихово пропадање: како киша симболично представља духовну оплодњу, сви предмети везани за време када је у дворцу живео Селим-Гиреј доживеће не само материјалну рестаурацију, него ће најпре захваљујући песнику, а потом и режисеру бити враћени у живот.

Последњи сегмент овог дела сценарија, у коме се паралелно говори о Пушкину и туристима, завршава се, као и прва новела, сликом гробља. На споменицима се налазе оригинални муслимански натписи, али се на њима виде и натписи које су приликом посета остављали туристи. За туристе је важно да оставе траг свога боравка у дворцу, без обзира на то што њихов покушај да овај простор учине својим има карактер рушења. Споменици оскрнављени натписима постају тако сведочанство сусрета различитих епоха. Туристи бацају коштице брескви на асфалт, што одговара библијском мотиву бацања семења на камен, док песник штапом раскопава земљу и „сахрањује“ коштицу, чиме режисер реализује библијску параболу о семену које мора умрети да би дало нови живот. Живот и смрт се непрестано преплићу на простору Бахчисараја.

Песник не може да напусти Бахчисарај кочијом којом је дошао јер га је долазак на ово место променио, зато он дворац напушта на коњу. Сценарио се завршава Пушкиновим стиховима, којима он најављује у поеми жељу за враћањем на Тавриду (Пушкин 1969: 51). Стихови су повод за Параџанова да прикаже како кретање Пушкина у сусрет таласима представља раскид са дотадашњим животом. Зеленило у које урања песник посредник је између високог и ниског, то је боја људског и боја буђења живота. Режисер у сценарију показује тријумф сакралне љубави над профаном па у новели „Смрт муслиманке“, кан пали кавез са кокошкама, баш као што је песник показао тријумф Марије над Заремом. Гробница је централно место од кога почиње Параџановљева прича, а завршава се када песник „сахрани“ своју платонску љубав писањем Бахчисарајске фонтане. Смрт је за Параџанова, као што смо навели, тренутак у коме се рађа уметничко дело (Параджанов 2001: 180). У епилогу Параџанов приказује Пушкинов одлазак у сусрет јужним плотским љубавима, које симболише Амазонка на коњу. ${ }^{8}$

Стварање поеме Бахчисарајска фонтана у Парашановљевом тумачењу било је завршно поглавље љубави која је почела као духовна блискост и завршава се стварањем дела о љубави која у романтичарском кључу не зна за границе (вер-

${ }^{8}$ На југу Пушкин је упознао Амалију Ризнич, Катарину Воронцову и Калипсо Полихорни које ће га инспирисати за бројна дела (Иезуитова 1995: 209-232). 
ске у случају Гиреја и старосне у Пушкиновом случају). Кретање песника од севера ка југу за режисера је кретање од духовног ка плотском. Не одређујући преимућство једне или друге врсте љубави, баш као ни Пушкин у својој поеми, Параџанов даје читаоцу увид у могућност стварања уметничких дела инспирисаних јужним плотским љубавима као што се и десило у Пушкиновом животу, а што симболизује појава Амазонке у последњој новели сценарија. Симболика фонтане је други проблем који решава Параџанов. Фонтана је пролаз ка духовном свету. Ова симболика разраста се у режисеровом сценарију на читав дворац. Туристи долазе у Бахчисарај у жељи да доживе просветљење, али га не доживљавају. Једини који прихвата небески дар и једини који види Пушкина као вечно живу фигуру је други уметник. Бахчисарајски дворац за аутора сценарија није само место сусрета истока и запада, Татара и руских владара - ово је посебно „Пушкиново“ место

\section{Цитирана литература}

Албваш, Морис. „Колективно и историјско памћење“. РЕЧ, часопис за књижевнос и културу и друштвена питања 56.2, 1999: 63-82.

Балакин, А. Ю., А. С. Бодрова. «Полицейское послание яко материал» (К творческой истории «Бахчисарайского фонтана»). Временник Пушкинской комиссии 31, 2013: 5-16.[Электронные публикации Института русской литературы РАН] http://lib2.pushkinskijdom.ru/Media/Default/PDF/Sborniki/VPK_31/\%D0\%92\% D0\%9F\%D0\%9A-31 \%D0\%91\%D0\%B0\%D0\%BB $\%$ D0 $\%$ B0 $\%$ D0 $\%$ BA $\%$ D0 $\%$ B 8 $\%$ D0 $\%$ BD- $\%$ D0 $\% 91 \%$ D0 $\%$ BE $\%$ D0 $\%$ B4\%D1\%80\%D0\%BE\%D0\%B2\%D0\%B0. pdf> 28.02. 2018

Барышников, В. Н., Б. П. Заостровцев, А. И. Филюшкин. «Империя, память и 'места памяти'». Вестник Санкт-Петербургского университета. История Сер. 2, Вып. 3, 2011: 84-89.

Бронштейн, А. И. «Трансформация легенды Фонтана Слез». Бахчисарайский историко-археологический сборник 1, 1997: 475-486.[Сайт общеисторического портала «Новый Геродот] < liberea.gerodot.ru/a_hist/fontana.htm> 28.02.2018.

Иезуитова, Раиса В. «'Утаенная любовь' Пушкина». [В:] Виролайнен М.Н. (ред.) Легенды и мифы о Пушкине. Санкт-Петербург: Академический проект, 1995 , $216-239$

Јаковљевић, Ана. Сергеј Параџанов: кинематографско читање поема Пушкина и Љермонтова: Библиотека катедре за славистику, Београд, сигн. СЛ МР 111

Куљић, Тодор. Култура сећања. Београд: Чигоја штампа, 2006.

Лотман, Юрий М. Семиосфера. Санкт-Петербург: «Искусство-СПБ», 2001.

Нора, Пьер. Проблематика мест памяти. Франция-память. Санкт-Петербург: Издательство Санкт-Петербургского университета, 1999. С. 17-50.

Параджанов, Сергей. «Если художнику не верят после сорока, то ему не поверят и на том свете...». Выступление перед творческой и научной молодежью Белоруссии 1 декабря 1971 года. Континент 150, 2011. [Журнальный зал] < http://magazines. russ.ru/continent/2011/150/p 73.html > 28.02.2018.

Черненко, Мирон М. «Проблема этнического кинематографа и 'казус' Параджанова». Киноведческие записки 6, 1990: 94-99.
Бахчисарајски двораи као место сећања код Александра Пучкина и Сергеја Параианова 283

Chevalier, Jean, Alain Gheerbrant. Rečnik Simbola. Banja Luka: Romanov, 2003

Howard, Jeremy Charles. From Baghçesary Salsabil to Bakhchisarai Fountain: The Transference of Tatar Triumph to Tears. [In:] J. C. Howard (ed.), By Force or By Will: The Art of External Might and Internal Passion. St Andrews: University of St Andrews, 2002, 177-190. [St Andrews Research Repository] https://researchrepository.st-andrews.ac.uk/handle/10023/671 28.02.2018.

\section{Извори}

Параджанов, Сергей И. Исповедь. Санкт-Петербург: Издательство «Азбука», 2001. Пушкин, Александар С. «Бахчисараски фонтан». [В:] А. С. Пушкин. Собрание сочинени в шести томах Т. 3, Москва: «Правда», 1969. Тынянов Юрий Н. Пушкин. Киев: «Дніпро», 1987

Анна Яковлевич Радунович

БАХЧИСАРАЙСКИЙ ДВОРЕЦ КАК МЕСТО ПАМЯТИ У АЛЕКСАНДРА ПУШКИНА И СЕРГЕЯ ПАРАДЖАНОВА

Резюме

Сравнительный анализ литературного сценария Дремлющй дворец Сергея Параджанова и поэмы Бахчисарайский фонтан Пушкина мы проводим исходя из теории памяти Хальбвакса поэмы Бахчисарайский фонтан Пуш и концепции места памяи Пьера Нора. Нскория создания текста поэмы - наглядное доказательство как воспоминания реконструируются под влиянием общества. Соллковение поэтического вымысла, личного восноминания и лслорического предания, оказалось спроецировано в сюжетную плоскость Бахчисарайского фонтана. Пушкин является главным герое сценария Паранджанова, и для режиссера важно показать, что легенда о Фонтане слез как месте воспоминаний сформировалась под влиянием жизненной ситуации поэта. Параджанов в сценарии решает проблемы соотношения автобиографической и коллективной памяти, и памяти и истории.

Ключевые слова: Пушкин, Параджанов, Фонтан слез, Бахчисарай, место памяти, сценарий, коллективная и личная память. 